\title{
ZMIANY OPINII UŻYTKOWNIKÓW SERWISÓW INTERNETOWYCH W HANDLU ELEKTRONICZNYM W LATACH 2017-2018
}

https://doi.org/10.33141/po.2018.09.05

\section{Witold Chmielarz, Tomasz Parys}

\section{Wprowadzenie}

G łównym celem opracowania jest identyfikacja dynamiki wykorzystania serwisów internetowych poprzez specyfikację czynników określających możliwości rozwoju handlu elektronicznego. Stanowi ono kontynuację badań prowadzonych przez autorów w latach poprzednich, których wyniki opublikowane zostały w pracy (Chmielarz Parys, 2017a). Podstawowe pytania badawcze nasuwające się $\mathrm{w}$ tym zakresie sprowadzają się do następujących problemów:

- jakie grupy komponentów i czynników szczegółowych w każdej grupie wpływają na kształtowanie relacji pomiędzy klientami a sklepami elektronicznymi? - w jakim stopniu, wg ankietowanych, elementy te wpływają na stan i rozwój handlu elektronicznego?

- jak kształtowała się dynamika zmian czynników wpływających na handel elektroniczny w ostatnich latach?

Polski rynek e-commerce osiąga obecnie wartość 36-40 mld zł (https://businessinsider.com.pl/finanse/handel/rynek-e-commerce-w-polsce-raport-gemiusa-za-2017-rok/ mpw8rs5). Handel elektroniczny jest dziś dynamicznie rozwijającą się branżą polskiej gospodarki. Prognozuje się, że do 2020 roku wartość tego sektora ma wzrosnać do 63 mld złotych. Z badań przeprowadzonych przez firmę PayU wynika, że $83 \%$ polskich internautów decyduje się na zakupy w Internecie przede wszystkim ze względu na dowolność czasową w ich robieniu i brak kolejek (http://www. portalspozywczy.pl/handel/wiadomosci/co-czeka-handelelektroniczny-w-polsce-w-2018-roku,153712.html).

Według danych za rok 2017, ponad połowa Polaków deklaruje, że robi zakupy w sieci. Z raportu firmy Gemius wynika, że w tymże roku już 54\% Polaków kupowało w sieci (https://www.gemius.pl/files/reports/E-commerce-w-Polsce-2015.pdf); to o 4 pkt. proc. więcej niż w roku 2016. Jest to dość duży wzrost, szczególnie jeżeli weźmie się pod uwagę, że dostęp do Internetu nie jest jeszcze $\mathrm{w}$ naszym kraju powszechny - odsetek korzystających z Internetu wynosi 79\% mieszkańców naszego kraju (http://www.portalspozywczy.pl/handel/wiadomosci/co-czeka-handel-elektroniczny-w-polsce-w-2018-roku,153712.html). Jako ciekawostkę podać należy, że coraz więcej osób uważa też zakupy online za bezpieczne. Podczas gdy w 2016 roku $43 \%$ ankietowanych uważało zakupy w sieci za ryzykowne, w 2017 roku opinię tę podzielało już tylko $38 \%$ osób (https://businessinsider.com.pl/finanse/
Przegląd Organizacji, Nr 9 (944), 2018, ss. 34-40 www.przegladorganizacji.pl @Towarzystwo Naukowe Organizacji i Kierownictwa (TNOiK)

handel/rynek-e-commerce-w-polsce-raport-gemiusaza-2017-rok/mpw8rs5). W rozwoju handlu elektronicznego można wyznaczyć kilka trendów. W 2017 roku najważniejszymi trendami były: personalizacja usług, darmowe dostawy oraz zastosowanie technologii mobilnych. W 2018 roku sytuacja wyglądała podobnie. W czołówce znalazły się także personalizacja wraz z zastosowaniem technologii mobilnych, do których w miejsce darmowych dostaw dołączyło zastosowanie sztucznej inteligencji w obsłudze systemów internetowych.

Literatura w zakresie omawianego zjawiska jest dość obszerna i szczegółowo charakteryzuje poruszane zagadnienie. $W$ poprzedniej pracy autorów przeprowadzono jej dokładną analizę, w związku z czym w niniejszym opracowaniu zostanie przedstawione jedynie jej uzupełnienie (Chmielarz, Parys, 2017a). W publikacjach poświęconych zagadnieniu handlu elektronicznego i jego rozwojowi w Polsce podejmowano wiele prób zdefiniowania determinant jego rozwoju. Początkowo jako determinanty rozwoju rynku e-commerce wskazywano między innymi: stan infrastruktury teleinformatycznej, wykształcone społeczeństwo, edukację internetową, profesjonalną administrację, stan i rozwój elektronicznego systemu transakcji (Szyda, 2014). Obecnie najsilniejszym czynnikiem zachęcającym do zakupów w sieci, według firmy Geminus, jest ich całodobowa dostępność (82\% wskazań). Pozostałymi czynnikami są (https://businessinsider.com.pl/finanse/ handel/rynek-e-commerce-w-polsce-raport-gemiusa-za-2017-rok/mpw8rs5): wygoda (44\%), prostota (nieskomplikowanie) (41\%), zakupy zajmujące mniej czasu niż stacjonarne (39\%), zakupy tańsze niż w sklepach stacjonarnych (33\%).

Przegląd literatury dostarcza ciekawych danych dotyczących determinant rozwoju handlu elektronicznego w konkretnych segmentach rynku, np. na rynku żywności (Grzywińska-Rąpca, Grzybowska-Brzezińska, 2016). Piśmiennictwo wskazuje także determinanty „zakupu usług" w podziale na ich grupy w kontekście rodzimego rynku. Tymi grupami są usługi edukacyjne, bankowe, ubezpieczeniowe oraz turystyczne. Wybierając usługi edukacyjne i bankowe, klienci na pierwszym miejscu stawiają jakość, a następnie cenę usług. W przypadku usług ubezpieczeniowych i turystycznych najistotniejsza jest również cena. Przy zakupie usług 
turystycznych i edukacyjnych decydującą determinantą jest marka. Prawie co piaty e-konsument usług bankowych i ubezpieczeniowych kieruje się przyzwyczajeniem (Wolny, 2012). Przykładem analiz branżowych są także opracowania z zakresu branży odzieży i obuwia. Determinantami dokonywania zakupów elektronicznych w tym sektorze są w pierwszej kolejności: atrakcyjność oferty pod względem dostępności produktów, łatwości zakupów oraz cena. Natomiast z czynników demotywujących do dokonywania zakupów za pośrednictwem sieci najwięcej wskazań otrzymały: „zakupy w sklepach stacjonarnych sprawiają mi większą przyjemność” oraz „korzystanie ze sklepów internetowych jest dla mnie zbyt skomplikowane". W opracowaniu wskazano na zależności pomiędzy opiniami a wiekiem respondentów (Supryn, Sobczyk, 2016). Literatura przedmiotu dostarcza również analiz dotyczących wybranych gałęzi przemysłu, w których sytuacja na naszym rodzimym rynku jest zestawiona $\mathrm{z}$ wymiarem ogólnoświatowym (Czajkowski, 2010). Dostępne są opracowania porównujące nasz rodzimy rynek z rynkiem europejskim (Jaciow i in., 2013). Można znaleźć opracowania dokonujące porównań tego zjawiska w kontekście różnych rynków w ujęciu geograficznym (narodowym). Prezentowane są one również $\mathrm{w}$ formie zestawień i porównań $\mathrm{w}$ wymiarze organizacji międzynarodowych (np. OECD), jak też poszczególnych operatorów (np. Amazon, Wallmart) (Konopielko i in., 2016). Literatura zwraca uwagę, że w ostatnich latach wskutek coraz większej liczby produktów i usług dostępnych za pośrednictwem sieci pojawił się nowy rodzaj określany mianem konsumenta nowej ery, a także coraz częściej „konsumentem digitalnym” (Krzepicka, 2016). Konsument taki korzysta ze zdobyczy technologicznych. Charakteryzuje go przede wszystkim niezależność, poszukuje informacji, podkreśla swoją indywidualność, angażuje się w procesy rynkowe oraz zbiera i dokonuje analizy bądź selekcji informacji.

Na podstawie badań ShoppingShow dotyczącego zwyczajów zakupowych Polaków określono zestaw szczególnych cech wyróżniających konsumenta digitalnego (Gieracz, 2014). Cechy takiego nowoczesnego klienta mogą być również analizowane jako determinanta rozwoju konkretnej branży, np. RTV/AGD (Szymański, 2016). Współczesny klient sklepów elektronicznych jest coraz częściej osobą młodą należącą do tzw. generacji Y, która mając swobodny dostęp do różnorodnych źródeł informacji $z$ jednej strony uodporniła się na szum informacyjny, a z drugiej stała się bardziej świadoma świata, w którym żyje. Taki klient należy do tzw. pokolenia sieci, dla którego można także zdefiniować zestaw specyficznych cech (Frąckiewicz, 2011). Najbardziej obszernych danych w zakresie determinant wykorzystania handlu elektronicznego dostarczają coroczne raporty firmy Geminus dotyczące praktycznie pełnego spektrum problemów związanych z sektorem e-commerce. Przykładowo raport za rok 2015 przedstawia determinanty przez pryzmat czynników, po pierwsze tych, które skłoniłyby osoby niekupujące do dokonania zakupów, po drugie tych, które osoby dokonujące zakupów zmotywowałyby do częstszego kupowania. I tak w pierwszej grupie najważniejszymi są dostawa (22\%) oraz koszty realizacji zamówienia (35\%) i czas jej realizacji (22\%). W drugiej grupie, tj. tych którzy dokonują zakupów w Internecie, 57\% badanych deklaruje, że czynnikiem, który zmotywowałby ich do bardziej intensywnych zakupów, są niższe koszty dostawy. Ten sam czynnik ma decydujący wpływ na decyzję o wyborze konkretnego sklepu (44\%) (https://www.gemius.pl/files/reports/E-commerce-w-Polsce-2015.pdf). Czynniki warunkujące rozwój zastosowań handlu elektronicznego są również przedstawiane $\mathrm{z}$ perspektywy poszczególnych jego sektorów. Choć zdecydowana większość opracowań dotyczy „klasycznego” handlu elektronicznego, tj. segmentu relacji między klientem a przedsiębiorstwem (sektor B2C), to nie brakuje opracowań dotyczących także innych sektorów, jak np. sektora handlu między przedsiębiorstwami (B2B) (Strzębicki, 2016).

\section{Metoda badawcza}

B iorąc pod uwagę własne doświadczenia wynikające z badań ankietowych handlu elektronicznego, badania przeprowadzone metodą CAWI (ang. Computer Associated Web Interview) w marcu 2017 i w maju 2018 roku oparto na własnym podejściu, składającym się z poniższych etapów: wybór i uzasadnienie testowej próby badawczej oraz próby docelowej, skonstruowanie prototypu ankiety na temat czynników wpływających na e-biznes w postaci serwisów dostępnych przez przeglądarki internetowe oraz aplikacje mobilne, weryfikacja merytoryczna pytań ankietowych na losowo wybranej testowej grupie aktywnych użytkowników e-handlu, skonstruowanie ostatecznej postaci ankiety oraz umieszczenie i przetestowanie jej $\mathrm{w}$ sieci, przeprowadzenie ankiet wśród potencjalnych użytkowników e-handlu, analiza i dyskusja wyników oraz wyciągnięcie wniosków z uzyskanych wyników. Wybór grupy badawczej nie był przypadkowy, należy do klasy wyborów wygodnych, modyfikowanych losowym wyborem grup studenckich. Ankietowani byli studentami wszystkich rodzajów studiów. Jako grupę testową wybrano grupę pierwszego roku studiów magisterskich specjalności e-Biznes po pracy projektowej dotyczącej oceny jakości witryn internetowych. Ankiety zarówno w postaci testowej, jak i ostatecznej udostępniono drogą elektroniczną, poziom zwrotności nie przekroczył 90\%, pomimo że studenci są taką grupą społeczną, która jest szczególnie otwarta na wszelkiego rodzaju innowacje i która jednocześnie kupuje najczęściej w Internecie (Batorski, 2015).

Ograniczeniem dokonanego wyboru, a jednocześnie największą jego zaletą był spodziewany między innymi wysoki udział osób posiadających długotrwały dostęp do smartfonów, tabletów, laptopów i komputerów stacjonarnych, nawet jeśli nie są najlepsze pod względem jakości. Granicą rozróżnienia pomiędzy tradycyjnym, przeglądarkowym handlem elektronicznym a handlem mobilnym nie były same urządzenia umożliwiające zakupy w sklepach, a ich oprogramowanie $-\mathrm{z}$ jednej strony dostęp do 
serwisów poprzez przeglądarki internetowe, $\mathrm{z}$ drugiej poprzez aplikacje na urządzenia mobilne.

Ankietę w pierwszym terminie w 2017 roku wypełniły 427 osoby, w tym - w postaci pełnej oraz prawidłowej ankietę wypełniło 381 osób, co stanowi 89,23\% respondentów. W drugim przypadku w 2018 roku - do ankiety przystąpiło 496 osób, z czego w postaci kompletnej ankietę wypełniło 373 osoby $(75,20 \%)$. W 2018 roku wśród ankietowanych było 66,76\% kobiet i 33,24\% mężczyzn. Zmiana struktury płci (6,73\% mniej kobiet) była spowodowana wylosowaniem do badania większej liczby grup na kierunku Zarządzanie, gdzie występuje większa liczba mężczyzn w stosunku do liczby kobiet niż na kierunku Rachunkowość, Finanse i Ubezpieczenia Społeczne. Przedział wiekowy respondentów wyniósł 22-55 lat, był tym samym nieznacznie wyższy niż rok temu, mediana zaś wyniosła 22 lata. Jest to wiek typowy dla studentów studiów licencjackich oraz pierwszych lat studiów magisterskich, których autorzy prosili o wypełnienie ankiety. Prawie 95\% ankietowanych było $\mathrm{w}$ wieku $\mathrm{z}$ przedziału 18-25 lat (o dwa punkty procentowe mniej niż w 2017 r.), ponad 2\% w wieku $26-30$ lat, 1,5\% z przedziału 31-35 lat i nieliczne osoby (4) z przedziału 36-55 lat. Wśród ankietowanych było ponad $51 \%$ studentów niepracujących, $48 \%$ studentów pracujących oraz niewielka (5 osób) liczba osób pracujących zawodowo, które wraz ze studentami testowały kolejne wersje ankiety. Wykształcenie średnie posiadało $91,42 \%$ osób - ankieta była głównie przeprowadzana wśród studentów stacjonarnych studiów licencjackich, co spowodowało o ponad 6\% wyższą liczbę studentów $\mathrm{z}$ wykształceniem średnim i prawie tyle samo mniejszy procent $\mathrm{z}$ wykształceniem licencjackim. Ukończenie studiów wyższych zadeklarowały jedynie 4 osoby. Ponad 52\% ankietowanych deklarowało pochodzenie $\mathrm{z}$ miasta o liczbie mieszkańców ponad 500 tys. (wzrost o $3 \%$ ), ponad $26 \% \mathrm{z}$ miast poniżej 50 tys. mieszkańców (spadek o 1\%), pozostałe grupy dotyczące miejsca zamieszkania kształtowały się podobnie jak rok temu. Prostota ankiety nie spowodowała dużej liczby przekłamań w wypełnieniu, a liczni respondenci (179 osoby) wypełniali rubryki dodatkowe.

Reasumując - próba wykorzystana w kolejnych badaniach miała podobną, ale nie identyczną strukturę ze względu na narzuconą częściową losowość badania (losowanie grup studenckich, w których przeprowadzono ankietę).

\section{Wyniki badań}

A nkieta zawierała trzydzieści cztery pytania merytoryczne oraz metryczkę. Była podzielona na dwie części: informacje infrastrukturalne (częstotliwość łączenia się z Internetem, wykorzystywane urządzenia oraz zakupy za pośrednictwem sieci) oraz czynniki pozytywnie i negatywnie wpływające na zakupy w sieci, podzielone na sześć kategorii grup.

Pierwsza grupa pytań dotyczyła charakterystyki wykorzystania przez wyszczególnioną grupę użytkowników Internetu dla dokonywania zakupów. Pozwoliło to ocenić wiarygodność ich odpowiedzi na pytania dotyczące czynników stymulujących i destymulujących rozwój handlu elektronicznego. Na pytanie dotyczące częstotliwości korzystania z Internetu 97,86\% respondentów odpowiedziało, że korzysta $\mathrm{z}$ niego kilka razy dziennie. Marginalne (w sumie 2,14\%) były odpowiedzi typu: nie mniej niż raz dziennie, nie mniej niż raz $\mathrm{w}$ tygodniu czy parę razy $\mathrm{w}$ miesiącu. W komunikacji z Internetem udział osób używających głównie smartfona wzrósł o 13,31\% i wynosi obecnie prawie $60 \%$ użytkowników. Zmalał natomiast udział osób używających kombinacji laptopa i smartfona o ponad 5\% i wynosi obecnie $26,01 \%$. Jeszcze bardziej zmalał udział osób używających samego laptopa - 5,31\%. Systematycznie maleje też liczba osób używających komputera stacjonarnego - w ostatnim badaniu ich udział wynosi już tylko 2,68\%. Pozostałe kombinacje urządzeń używanych do łączności z Internetem (np. komputer stacjonarny i tablet, laptop i tablet) również systematycznie maleją, w ciągu ostatniego roku ich dział zmniejszył się o 3,36\%. Ponad połowa $(56,84 \%)$ respondentów należy nie tylko do aktywnych użytkowników Internetu, ale również do aktywnych klientów sklepów internetowych. W kategorii tej nastąpił wzrost o 5,39\%. Wśród nich 7,51\% dokonuje zakupów nie mniej niż raz w tygodniu, a 49,33\% nie mniej niż raz w miesiącu. Bardzo rzadko zakupy w Internecie przeprowadza 38,07\% ankietowanych, co stanowi spadek o prawie $4 \%$. Tylko $1,07 \%$ wcale nie korzysta $\mathrm{z}$ tej formy zakupów.

Wyniki uzyskane w pierwszej grupie pytań zdawały się dobrze wyrokować o możliwościach prawidłowej oceny przez badaną grupę osób ograniczeń i czynników pobudzających handel elektroniczny. Kolejna grupa pytań dotyczyła więc już zasadniczego problemu determinant, podzielonych na szereg kategorii: ekonomiczne, organizacyjne, prawne, bezpieczeństwa, socjopsychologiczne i technologiczne.

W grupie komponentów ekonomicznych pierwszym z wyszczególnionych czynników szczegółowych była cena urządzenia do komunikacji $\mathrm{z}$ Internetem (smartfon, tablet, laptop itp.). W dobie powszechności smartfonów okazało się, że najwięcej odpowiedzi wskazało na średni $(36,84 \%)$ wpływ ceny urządzenia na prowadzenie przy jego pomocy handlu elektronicznego, który się niemal nie zmienia od roku. Natomiast o 3,5\% zwiększyła się ilość opinii o najwyższym i wysokim wpływie ceny urządzenia na handel elektroniczny, które teraz mają prawie $29 \%$ udziału we wszystkich opiniach. Zmniejszyła się także nieco liczba wypowiedzi optująca za żadnym wpływem ceny urządzenia na udział w handlu elektronicznym. Rok wcześniej w komentarzach studenci podkreślali, że smartfon „wypada mieć, bez względu na cenę", w tym roku stało się to mniej istotne. Podobnie oceniony został koszt za połączenie z Internetem. Jedyną oceną, która wzrosła w znaczący sposób w stosunku do poprzedniego roku, była ocena wskazująca na mały wpływ ceny Internetu na handel elektroniczny. Wzrosła ona o $4 \%$ kosztem oceny świadczącej o średnim i wysokim wpływie. Nadal niemal $33 \%$ ocen 
mówi o średnim wpływie ceny dostępu do Internetu na handel elektroniczny. Zupełnie inaczej wygląda sytuacja w przypadku cen towarów i usług w Internecie. Aż blisko 70\% ankietowanych uważa, że wpływ ceny na popularność zakupów w sklepach internetowych jest najwyższy i wysoki. Udział tych opinii spadł w ciągu roku o blisko 7 punktów procentowych, kosztem wzrostu opinii, że jest on średni $(21,18 \%$ - wzrost o ponad $5 \%)$ i mały (5,36\% - wzrost o ponad $1 \%)$. Pytaniem niejako uzupełniającym i sprawdzającym, w stosunku do poprzedniego, było dodanie do ceny towaru/usługi ceny dostawy. Najwięcej osób - blisko 69\% - optowało wciąż za najwyższym i wysokim wpływem na uczestnictwo $\mathrm{w}$ handlu elektronicznym, chociaż udział ten zmniejszył się o 6,69\%. O niemal tyle samo zwiększył się w tym czasie udział opinii o średnim wpływie tego zjawiska na korzystanie $\mathrm{z}$ handlu elektronicznego. W grupie determinant ekonomicznych najistotniejsza dla klientów okazała się niska cena towaru/usługi oraz dostawy w porównaniu ze sklepem tradycyjnym. W najmniejszym stopniu wpływa na handel elektroniczny cena za połączenie $z$ Internetem.

Następne pytania dotyczyły grupy czynników organizacyjnych. Okazało się, że najwyższy i wysoki wpływ na ocenę handlu elektronicznego ma sprawna i szybka organizacja dostaw. Uważa tak prawie $85 \%$ ankietowanych. Brak wpływu tego czynnika zauważa 14,48\% respondentów. Podobnie ma się sprawa z rozwiniętym (więcej niż jeden rodzaj płatności) systemem płatności. Im więcej możliwości zapłaty i im bardziej jest ona łatwiejsza, tym klienci chętniej dokonują zakupów. Dlatego zapewne prawie $84 \%$ ankietowanych sądzi, że czynnik ten w wysokim stopniu decyduje o chęci zakupów, co stanowi wzrost o ponad $5 \% \mathrm{w}$ stosunku do roku ubiegłego. Interesujące wyniki uzyskano, badając wpływ sprawnych i kompetentnych dostawców usług internetowych na postrzeganie handlu elektronicznego. Pomimo upływu lat (sklepy internetowe $w$ naszym kraju są już od ponad 20 lat) nadal funkcjonuje w społeczeństwie negatywna opinia na temat jakości usług serwowanych przez dostawców usług internetowych (Wielki, 2012). Być może to właśnie powoduje tak wysoki odsetek (ponad 42\%) osób oceniających, że występuje wysoki i najwyższy wpływ braku sprawnych i kompetentnych dostawców usług internetowych na postrzeganie handlu elektronicznego, a dodatkowo blisko jedna trzecia ocenia go jako średni. Różnice pomiędzy opiniami z 2017 r. a z 2018 roku są niewielkie i nie przekraczają 2,20\%. Jednym $z$ decydujących w tej grupie komponentów wydaje się również wpływ złej jakości serwisu internetowego na korzystanie $\mathrm{z}$ handlu elektronicznego. Otóż prawie 65\% respondentów są$\mathrm{dzi}$, że decyduje on w stopniu najwyższym i wysokim, a tylko w sumie prawie $10 \% \mathrm{w}$ małym lub żadnym stopniu. W stosunku do roku uprzedniego nie nastapiły tu znaczące przesunięcia opinii. Brak sprawnie działającej interakcji z klientami (obsługi klienta) w opinii ankietowanych aż w 54\% w najwyższym i wysokim i $31,10 \%$ $\mathrm{w}$ stopniu średnim wpływa na korzystanie $\mathrm{z}$ handlu elektronicznego, a tylko ponad $15 \% \mathrm{w}$ stopniu małym lub w ogóle nie ma wpływu. I tu różnice pomiędzy wynikami z 2017 r. a z 2018 r. są niewielkie i nie przekraczają 2,65\%. W grupie czynników organizacyjnych najistotniejszym czynnikiem był sprawny i szybki system dostawy (85\% wskazań). Najmniej istotny wydawał się respondentom brak sprawnych i kompetentnych usług internetowych (jedynie 43\% wskazań).

Wpływ czynników prawnych objął jedynie dwa pytania. Pierwsze $\mathrm{z}$ nich dotyczyło utrudnień prawnych w dostawie niektórych towarów/usług (np. cła, przepisy lokalne). W najwyższym i wysokim stopniu taki wpływ zauważyło ponad $38 \%$ respondentów (o 2,5\% mniej niż przed rokiem). Natomist duża różnica - prawie $12 \%$ - wystąpiła w opiniach o średnim wpływie tego czynnika na wykorzystanie handlu elektronicznego. Odbyło się to kosztem wszystkich innych opinii, a najbardziej (5,38\%) opinii o braku takiego wpływu. Drugie z pytań koncentrowało się na nienadążaniu przepisów prawnych za rozwojem nowych technologii. Ponad 65\% ankietowanych uważa, że wpływ ten jest mały albo średni, a jedynie ponad $24 \%$ opowiedziało się za wpływem wysokim i najwyższym. Nie jest więc to cecha uważana za najistotniejszą przy korzystaniu $\mathrm{z}$ handlu elektronicznego, a relacje pomiędzy opiniami nie zmieniły się istotnie w ciągu ostatniego roku. Wśród czynników prawnych największe znaczenie miały utrudnienia prawne w dostawie niektórych towarów lub usług. Ocena drugiego czynnika - niedostatki w przepisach regulujących sprzedaż towarów i usług - była bardzo zróżnicowana - od wpływu średniego po żaden.

Czynniki bezpieczeństwa wpływające na handel elektroniczny uwzględniono w kolejnych pytaniach. Pierwsze $\mathrm{z}$ nich dotyczyło braku bezpieczeństwa transakcji w Internecie ze szczególnym uwzględnieniem możliwości przejęcia i/lub utraty danych. Odpowiedzi mówiące o najwyższym i wysokim wpływie braku tego rodzaju bezpieczeństwa przekraczają 57\%. Razem z opiniami o średnim wpływie tego czynnika mamy do czynienia z 83\% udziełem opinii o istotności tego czynnika. $\mathrm{Na}$ drugim biegunie - czyli odpowiedzi o małym lub braku takiego wpływu przekraczają jedynie $17 \%$ wszystkich odpowiedzi. Najbardziej - o prawie $6 \%$ wzrosły w ciągu roku opinie o najwyższym i wysokim wpływie tego czynnika. Drugi problem dotyczył wpływu słabej ochrony danych osobowych w trakcie posługiwania się narzędziami handlu elektronicznego. Tu rozkład odpowiedzi jest niemal identyczny: 56\% respondentów opowiedziało się za najwyższym wpływem oraz wysokim, prawie $20 \%$ o małym lub braku takiego wpływu. W sumie potwierdza to tezę o istotności kwestii bezpieczeństwa transakcji i bezpieczeństwa danych osobowych dla rozwoju handlu elektronicznego. W ciągu ostatniego roku o prawie $4 \%$ wzrosła ocena dotycząca najwyższego i wysokiego wpływu tego czynnika na handel elektroniczny. Zwrócono też uwagę na niedoskonałości technologii umożliwiające ataki hakerów. I tu kwestie bezpieczeństwa są najistotniejsze w najwyższym i wysokim stopniu, jak $\mathrm{w}$ roku poprzednim dla prawie $50 \%$ respondentów, 
w małym i nieistotnym dwukrotnie mniej - ponad 22\%. Wśród czynników bezpieczeństwa najbardziej istotnym czynnikiem był brak bezpieczeństwa transakcji w Internecie, mniejszą rolę przywiązywano do słabej ochrony danych osobowych i niedoskonałości technologii umożliwiającej ataki hakerów.

Wpływ czynników socjopsychologicznych rozpatrywano wg kolejnych kryteriów. Pierwsze z nich dotyczyło oporu przed używaniem nowych technologii. W tym zakresie prawie $40 \%$ ankietowanych opowiedziało się za najwyższym i wysokim wpływem na handel elektroniczny tego czynnika. W stosunku do roku ubiegłego nastąpił wzrost o ponad 6\%. Odbyło się to kosztem opinii o żadnym wpływie na handel elektroniczny, które to opinie zmalały w ciągu roku o prawie $11 \%$. Następnie rozważany jest wpływ nauczenia się posługiwania Internetem i urządzeniami do jego wykorzystania. Wyniki są podobne do poprzednich. Ponad $38 \%$ opinii mówiące o najwyższym oraz wysokim stopniu wpływu tego czynnika na handel elektroniczny, zaś prawie 30\% w małym lub żadnym stopniu. W ciągu ostatniego roku opinia na temat jego wpływu zmieniła się na korzyść najwyższego, wysokiego i średniego wpływu o prawie $14 \%$, a zmalała o tyle samo w przypadku małego lub braku wpływu.

Ciekawie wygląda zestawienie wyników wpływu kryterium braku zaufania do tej formy zdalnej sprzedaży oraz powiązanego z nim braku przyzwyczajeń (nawyku) do formy zdalnej sprzedaży. O ile wpływ pierwszego kryterium jest oceniany bardzo wysoko (ponad 50\%), o tyle drugiego - o 16 punktów procentowych mniej - prawie 34\%. Kwestia zaufania wydaje się w tym przypadku znacznie istotniejsza niż przyzwyczajenia do tej formy sprzedaży. Może to wynikać z faktu, że w Polsce nie było w latach osiemdziesiątych XX wieku przyzwyczajenia do poprzedzającej, a podobnej formy sprzedaży przez telefon (z powodu braku dostępności do telefonów stacjonarnych). Ostatnim $z$ rozpatrywanych kryteriów była niechęć do jakiegokolwiek działania (np. lenistwo). W tym przypadku najwięcej było odpowiedzi mówiących o małym $(27,61 \%)$ lub średnim $(23$, $86 \%)$ wpływie tego czynnika na wykorzystanie handlu elektronicznego. W ostatnim roku zmiany w opinii na ten temat nie przekroczyły 3,30\%. Wśród czynników socjopsychologicznych największą rolę odgrywały czynniki braku zaufania i przyzwyczajeń do tej formy sprzedaży, z pozostałych podobne znaczenie miały opory kulturowe dotyczące tradycji sprzedaży. Pozostałe czynniki okazały się mało istotne.

Już przeprowadzona weryfikacja testowej wersji ankiety pokazała, że ankietowani tej populacji wyjątkowo dużą wagę przypisują uwarunkowaniom technologicznym. W tej grupie wmieniono najwięcej pytań szczegółowych. I tak 64,3\% respondentów uważa, że słaba jakość i zbyt wolna transmisja danych (występująca na niektórych obszarach Polski) w najwyższym i wysokim stopniu wpływa na korzystanie $\mathrm{z}$ handlu elektronicznego. Jedynie nieco ponad $8 \%$ nie widzi w tym problemu. $\mathrm{W}$ pytaniu tym $\mathrm{w}$ ciągu ostatniego roku nie nastapiły znaczące (nie przekroczyły 3,2\%) zmiany w opinii respondentów. Podobne wyniki uzyskano w odpowiedzi na uzupełniające pytanie o brak zasięgu sieci komórkowej i sieci WiFi na wolumen handlu elektronicznego. W odpowiedziach przeważa opinia $(68,1 \%)$ o wysokim oraz najwyższym stopniu wpływu tego zjawiska na korzystanie $\mathrm{z}$ handlu elektronicznego i podobnym udziale jak uprzednio małego oraz braku wpływu na to zjawisko. W ciągu ostatniego roku nastąpiły zmiany nieprzekraczające $1 \%$ wielkości. W przypadku niedoskonałości technologii powodującej trudności w obsłudze serwisów internetowych rozkład opinii jest bardziej równomierny, tym niemniej przewagę ma opinia o najwyższym i wysokim (46,38\%) oraz średnim (42,36\%) wpływie tego czynnika na wykorzystanie e-handlu. Ta tendencja do wyrównywania opinii w kierunku średniej ugruntowuje się w wielu czynnikach - w tym przypad$\mathrm{ku}$ jest spowodowana 3,5\% wzrostem opinii o średnim wpływie i blisko $3 \%$ spadku opinii o najwyższym i wysokim wpływie na korzystanie z elektronicznego handlu. Bardziej szczegółowe pytanie o wpływie na rozwój handlu elektronicznego witryn $\mathrm{z}$ dobrze zaprojektowanym i przyjaznym interfejsem oraz wygodnym sposobem robienia zakupów w sklepie internetowym pokazuje rozkład opinii pomiędzy wpływem najwyższym i wysokim $(50,67 \%)$ a średnim $(33,78 \%)$ poziomem opinii. Opinie o najwyższym i wysokim wpływie tego czynnika stają się coraz bardziej wyraźne - w ostatnim roku wzrosły o 5,26\% głównie kosztem opiniii o wpływie średnim. Wraz z latami użytkowania handlu elektronicznego rosną więc wyraźnie wymagania użytkownika względem jakości serwisów, z którymi się kontaktują. Wpływ „tłoku" i spiętrzenia ruchu w sieci rozkłada się pomiędzy opinią o najwyższym i wysokim $(37,80 \%)$, średnim $(30,03 \%)$ a małym $(25,74 \%)$ wpływie na wykorzystanie handlu elektronicznego. Opinia o najwyższym i wysokim wpływie tego czynnika wzrosła w ciągu ostatniego roku o ponad $11 \%$. Podobna sytuacja nastąpiła w przypadku zapytania o częste zmiany wizualizacji serwisów firmowych, zmuszające do zmiany przyzwyczajeń w obsłudze. O małym wpływie zadecydowało ponad $35 \%$ respondentów, o średnim prawie $29 \%$. Użytkownicy często przyzwyczajają się do korzystania z serwisów i nie odstręczają ich nawet zmiany związane z jego unowocześnianiem. Ostatnie z pytań ankiety dotyczyły relacji pomiędzy handlem elektronicznym tradycyjnym („przeglądarkowym”) a mobilnym opartym na aplikacjach mobilnych. Pierwsze $\mathrm{z}$ nich dotyczyło wpływu braku wersji stron dedykowanych na urządzenia mobilne dla serwisów sklepowych. Prawie 39\% ankietowanych oceniło go jako najwyższy i wysoki, prawie $32 \%$ jako średni, a prawie $24 \%$ jako mały. W ciągu ostatniego roku nastąpiła prawie $4,5 \%$ zmiana in plus w kierunku opinii o najwyższym i wysokim wpływie tego czynnika na handel elektroniczny, głównie kosztem spadku wpływu średniego $(6,42 \%)$. Nie pokrywa się to z procentem wykorzystania urządzeń mobilnych do kontaktów z Internetem. Inne wartości przyjęły zmiany związane $\mathrm{z}$ taką cechą, jak: niefunkcjonalny lub zbyt mały ekran 
urządzenia mobilnego (smartfon) używanego w handlu mobilnym. Najwięcej osób opowiedziało się za małym i średnim wpływem (po 30,56\%), Najwyższy i wysoki wpływ osiągnął $27 \%$ i ma tendencje spadkowe (ponad $2 \%$ w ciągu roku). Wydaje się, że przeciętna wielkość ekranu rzędu 5, 6 cali jest wystarczająca dla większości użytkowników. Ostatnie z pytań dotyczyło tak banalnej $z$ pozoru rzeczy, jak zbyt słaba bateria urządzenia mobilnego (smartfona). Ale, co ciekawe, ta cecha aż w blisko 36\% została oceniona jako mająca najwyższy lub wysoki wpływ na funkcjonowanie handlu elektronicznego, a tylko $24 \%$ oceniło wpływ tego czynnika jako mały lub 19\% jako czynnk niemający wpływu na handel elektroniczny. Opinie te nie zmieniły się istotnie (poniżej 2,1\%) w ciągu ostatniego roku. Determinanty technologiczne okazały się bardzo istotne dla respondentów. Wśród nich zdecydowanie przeważała obawa o połączenia słabej jakości i zbyt wolna transmisja danych oraz tłok i spiętrzenie ruchu w sieci. Na trzecim miejscu znalazł się brak zasięgu sieci komórkowej i sieci WiFi na wybranych obszarach. Pozostałe czynniki miały według nich mniejsze znaczenie dla korzystania $\mathrm{z}$ handlu elektronicznego.

\section{Podsumowanie}

W związku z powyższymi wynikami nasuwają się następujące wnioski ogólne. Biorąc pod uwagę maksymalne średnie uzyskane w każdej grupie kryteriów, pierwsze miejsce wśród średnich procentowo udzielonych przez ankietowanych odpowiedzi zajmują:

- o najwyższym i wysokim wpływie na handel elektroniczny - grupa kryteriów organizacyjnych - 65,95\% (o $10 \%$ więcej niż przed rokiem), $20 \%$ więcej niż średnia w tym zakresie w roku bieżącym, oraz technicznych i bezpieczeństwa 53,89\% (prawie 8\% więcej niż średnia w tej kategorii);

- o średnim wpływie - najistotniejsze były czynniki ekonomiczne - 49,15\%, ponad 16\% więcej niż średnia, w poprzednim roku były to czynniki techniczne i technologiczne - 32,84\%;

- o małym wpływie - prawne - 22,79\% (poprzednio - 25,33\%);

- bez wpływu - socjopsychologiczne - 11,06\% (poprzednio - 12,71\%).

Gdybyśmy brali pod uwagę tylko te wskaźniki, to decydującą rolę dla handlu elektronicznego należałoby pokładać w czynnikach organizacyjnych oraz bezpieczeństwa, niewiele w tyle poza nimi pozostają czynniki ekonomiczne. W ubiegłym roku na pierwszej pozycji znajdowała się grupa czynników bezpieczeństwa, na drugim organizacyjne.

Biorąc pod uwagę minimalne średnie uzyskane w każdej grupie kryteriów, pierwsze miejsce wśród średnich procentowo udzielonych przez ankietowanych odpowiedzi zajmują:

- o najwyższym i wysokim wpływie - czynniki prawne

- 31,23\% (poprzednio socjopsychologiczne - 24,56\%);

- o średnim wpływie - organizacyjne 23,63\% (poprzed- nio $22,84 \%)$;

- o małym wpływie- organizacyjne 7,24\% (poprzednio 7,99\%);

- bez wpływu - bezpieczeństwa 3,84\% (poprzednio organizacyjne - 1,36\%).

Jeśli bralibyśmy pod uwagę tylko minimalne średnie grupowe, to najmniejszą wage ankietowani przywiązują do czynników prawnych oraz organizacyjnych.

Ranking czynników szczegółowych w analizowanych grupach wskazuje na inne preferencje. Przedstawiał się on następująco:

- sprawny i szybki system dostawy (bez zmian w stosunku do roku ubiegłego - 85,00\%) - determinanty organizacyjne;

- niska cena ogólna (obejmująca również cenę dostawy) w sklepie internetowym w porównaniu ze sklepem tradycyjnym (obecnie $68,90 \%$, w roku ubiegłym - 75,59\%) - determinanty ekonomiczne;

- brak zasięgu sieci komórkowej i sieci WiFi na wybranych obszarach (obecnie 68,10\%, w roku ubiegłym - 68,77\%) - determinanty techniczne i technologiczne;

- brak bezpieczeństwa transakcji (możliwość przejęcia/utraty danych) w Internecie (obecnie 57,37\%, rok wcześniej - 51,44\%) - determinanty bezpieczeństwa;

- opór przed używaniem nowych technologii 56,03\%, spadek o $2 \%$ w stosunku do roku ubiegłego - czynniki socjopsychologiczne;

- utrudnienia prawne $\mathrm{w}$ dostawie niektórych towarów i usług - 38,07 - spadek o 1,5\% - determinanty prawne.

Najwięcej istotnych odpowiedzi (wskazujących na najwyższy i wysoki wpływ na handel elektroniczny) sytuuje się w grupie determinant organizacyjnych. W pozostałych trzech grupach (ekonomicznych, technicznych i technologicznych oraz bezpieczeństwa) wskazania te są niższe. Brak jest natomiast takich wskazań dla grupy wskaźników prawnych i socjopsychologicznej. Dotychczasowe badania (Chmielarz, Parys, 2017b) wskazywały raczej na dominację wskaźników technicznych i technologicznych oraz ekonomicznych. Coraz mniej istotne dla klientów handlu elektronicznego są natomiast wskaźniki bezpieczeństwa, co widać przez porównanie $\mathrm{z}$ wynikami $\mathrm{z}$ roku ubiegłego.

Zestaw tegorocznych determinant może stać się istotną wskazówką dla analityków i projektantów, uświadamiającą im, jakie czynniki powinni brać pod uwagę przy konstruowaniu poszczególnych serwisów. Dla celów projektowych należałoby zapewne szerzej uwzględnić ich odzwierciedlenie w szczegółowych komponentach serwisów. Powyższe badanie wskazuje jednak pośrednio na zmiany mentalności zachodzące w społeczeństwie w porównaniu z sytuacją sprzed roku. Przywiązywanie mniejszego znaczenia do bezpieczeństwa stwierdzono również w trakcie badania zakupów mobilnych (Chmielarz, Parys, 2017c). Dalsze badania powinny więc prowadzić $\mathrm{w}$ kierunku wykorzystania uzyskanych wyników w procesie projektowania oraz tworzenia serwisów sklepów internetowych. Drugi 
problem, który wart jest rozpatrzenia, to marginalnie ujęty w bieżących badaniach problem czynników determinujących wykorzystanie handlu elektronicznego dla tradycyjnego (przeglądarkowego) oraz mobilnego aplikacyjnego trybu dostępu. Trzecią sprawą powinno być zbadanie rozgraniczenia determinant pomiędy handlem tradycyjnym via sklepy internetowe a giełdami typu allegro czy e-bay. Badania powinny być kontynuowane $\mathrm{w}$ przyszłym roku pod kątem zmian w zakresie determinant handlu elektronicznego w ciągu pełnych trzech lat.

\section{prof. dr hab. Witold Chmielarz \\ Uniwersytet Warszawski \\ Wydział Zarządzania \\ e-mail: witold@chmielarz.eu}

\section{dr Tomasz Parys \\ Uniwersytet Warszawski \\ Wydział Zarządzania \\ e-mail: tomasz.parys@uw.edu.pl}

\section{Bibliografia}

[1] Batorski D. (2015), Technologie i media $w$ domach i $w \dot{z} y$ ciu Polaków, [w:] J. Czapiński, T. Panek (red.), Diagnoza społeczna 2015. Warunki i jakość życia Polaków - Raport, Warszawa, Nr 9, tom 4, s. 373-395.

[2] Chmielarz W., Parys T. (2017a), Czynniki warunkujace wykorzystanie handlu elektronicznego $w$ sklepach internetowych $z$ punktu widzenia użytkowników indywidualnych, „Studies \& Proceedings of Polish Association for Knowledge Management", Nr 8, s. 4-15.

[3] Chmielarz W., Parys T. (2017b), Determinants of the Use of e-commerce in Online Shops in the Polish Market from the Perspective of Individual Customers, [in:] D. Bork, E.T. Miron (eds.), Proceedings of 5th International Conference on Serviceology, OMiLAB, Vienna, pp. 29-37.

[4] Chmielarz W., Parys T. (2017c), The Use of Mobile Technologies in e-commerce, [in:] L. Gómez Chova, A. López Martínez, I. Candel Torres (eds.), ICERI 2017 Proceedings, IATED Academy, Sevilla, pp. 4008-4016.

[5] Czajkowski T. (2010), Handel elektroniczny w przemyśle tekstylno-odzieżowym, Zeszyty Naukowe Politechniki Łódzkiej, Nr 1061, s. 5-21.

[6] Frąckiewicz E. (2011), Aktywność zakupowa klientów $w$ sieci i jej determinanty, „Studies \& Proceedings of Polish Association for Knowledge Management", Nr 51, s. 5-16.

[7] Gieracz M. (2014), Zwyczaje zakupowe „zniecierpliwionych” klientów, „Marketer+. Przewodnik po marketingu", Nr 3, s. 207-214, https://marketerplus.pl/numery/ marketer-3-2014, data dostępu: 12.06.2018 r.

[8] Grzywińska-Rąpca M., Grzybowska-Brzezińska M. (2016), Determinanty e-zakupów na rynku żywności, „Roczniki Kolegium Analiz Ekonomicznych”, Nr 40, s. $469-478$.
[9] https://businessinsider.com.pl/finanse/handel/rynek-e-commerce-w-polsce-raport-gemiusa-za-2017-rok/ mpw8rs5, data dostępu: $12.06 .2018 \mathrm{r}$.

[10] https://www.gemius.pl/files/reports/E-commerce-w-Polsce-2015.pdf, data dostępu: 16.05. 2018 r.

[11] http://www.portalspozywczy.pl/handel/wiadomosci/ co-czeka-handel-elektroniczny-w-polsce-w-2018-ro$\mathrm{ku}, 153712 . \mathrm{html}$, data dostępu: 11.05.2018 r.

[12] Jaciow M., Wolny R., Stolecka-Makowska A. (2013), E-konsument $w$ Europie - komparatywna analiza zachowań, Helion, Gliwice.

[13] Konopielko Ł., Wołoszyn M., Wytrębowicz J. (2016), Handel elektroniczny, ewolucja i perspektywy, Oficyna Wydawnicza Uczelni Łazarskiego, Warszawa.

[14] Krzepicka A. (2016), Wspótczesny konsument - konsument digitalny, Studia Ekonomiczne. Zeszyty Naukowe Uniwersytetu Ekonomicznego w Katowicach, Nr 255, s. 207-214

[15] Strzębicki D. (2016), Czynniki rozwoju rynków elektronicznych B2B, „Handel Wewnętrzny”, Nr 3, s. 329-340.

[16] Supryn S., Sobczyk G. (2016), Motywy i ograniczenia e-zakupów odzieży i obuwia w Polsce, „Problemy Zarządzania”, Nr 1(57), tom 14, s. 176-191.

[17] Szyda M. (2014), Ekonomiczne uwarunkowania rozwoju handlu internetowego w Polsce, Prace Naukowe Uniwersytetu Ekonomicznego we Wrocławiu, Nr 347, s. $454-463$.

[18] Szymański G. (2016), Cechy e-klientów istotna determinanta rozwoju branży RTV/AGD sektora e-commerce, "Marketing i Zarządzanie”, Nr 3(44), s. 197-206.

[19] Wielki J. (2012), Modele wplywu przestrzeni elektronicznej na organizacje gospodarcze, Wydawnictwo Uniwersytetu Ekonomicznego we Wrocławiu, Wrocław.

[20] Wolny R. (2012), Polski konsument na rynku usług, „Konsumpcja i Rozwój”, Nr 1, s. 117-129.

\section{Changes in the Opinions of Website Users in e-commerce in the Years 2017-2018}

\section{Summary}

The main purpose of this article is to identify the changes in factors that have had an impact on the use of e-commerce opportunities in Poland in 2017-2018. The conclusions contained in the study are based on surveys conducted with the use of the CAWI method on individual, active Internet users. The structure of the work includes a presentation of the problem based on the literature background, methodological assumptions of the study, its results and their discussions and conclusions. The main achievements of the Authors include identification of factors that have been affecting electronic business in recent years, specification and analysis of changes, comparative analysis of results and recommendations for web designers.

\section{Keywords}

electronic commerce, mobile commerce, opinions of the use of e-commerce 